\title{
Cloud Point Extraction and Spectrophotometric Determination of Uranium (VI) in Water Samples after Mixed Micelle-Mediated Extraction Using Chromotrope 2R as Complexing Agent
}

\author{
M. B. Gholivand, ${ }^{*}$ M. Omidi, and M. Khodadadian
}

Faculty of Chemistry, Razi University, Kermanshah, Iran

\begin{abstract}
A rapid, selective and sensitive method for the preconcentration and determination of uranium (VI) by cloud point extraction (CPE) was developed. The method was based on the color reaction of 5.00 ng mL $\mathrm{mL}^{-1}$ uranium (VI) with $1.5 \times 10^{-4} \mathrm{~mol} \mathrm{~L}^{-1}$ of chromotrope $2 \mathrm{R}$ in the presence of $0.015 \mathrm{~mol} \mathrm{~L}^{-1}$ potassium iodide at $\mathrm{pH} 8$ in HEPES buffer and mixed micelle-mediated extraction of complex. The mixture of a nonionic surfactant $\left(0.2 \%(v / v)\right.$ of (Triton X-114) and a cationic $\left(2.0 \times 10^{-4} \mathrm{~mol} \mathrm{~L}^{-1}\right.$ of CTAB) was utilized as a suitable micellar medium for preconcentration and extraction of uranium (VI) complexes. Effect of extraction and reaction parameters was studied and optimum parameters were established. The analytical characteristics of the method (e.g. linear range, limit of detection, preconcentration and improvement factors) were obtained. Linearity was obeyed in the range of $0.2-10 \mathrm{ng} \mathrm{mL}^{-1}$ of uranium (VI) with a detection limit of $0.035 \mathrm{ng} \mathrm{mL}^{-1}$. The diverse ion effect of some anions and cations on the extraction efficiency of target ions was tested. The proposed method was successfully applied for the determination of uranium (VI) in various water samples. (doi: 10.5562/cca1922)
\end{abstract}

Keywords: mixed micellar medium; cloud point extraction; spectrophotometry; uranium (VI), chromotrope $2 \mathrm{R}$

\section{INTRODUCTION}

Uranium poses health risks because of its toxicity, primarily to the kidneys, and is known to cause acute renal failure as well as delayed (several weeks or months) kidney problems. ${ }^{1}$ Uranium presents a radiological hazard because the metal and its decay products have been demonstrated to deposit in bones and cause cancer and birth defects. ${ }^{2}$ The major sources of uranium in the environment are industrial effluents and other wastes, primarily due to mining and weapons manufacturing. ${ }^{3}$ Uranium toxicity and mobility is highly dependent on its oxidation state, being the oxidation state +VI the most toxic. The maximum allowed concentration of uranium in drinking water is $20 \mu \mathrm{g}$ per liter. Thus, highly sensitive methods are required for preconcentration and determination of uranium in water samples. ${ }^{4,5}$ However, conventional spectrometric analytical techniques such as flame atomic absorption spectrometry (FAAS), graphite furnace atomic absorption spectrometry (GFAAS) and inductively coupled plasma optical emission spectrometry (ICP OES) cannot be used for determination of trace amounts of ura- nium. Low sensitivity, ${ }^{6,7}$ the problem with the pyrolysis temperature ${ }^{6}$, uranium carbides formation in a graphite furnace ${ }^{8}$ are drawbacks of these methods. Considering this, inductively coupled plasma mass spectrometry (ICP-MS) is a good alternative for the determination of uranium at low concentrations but is very expensive.

Considering the low sensitivity of analytical techniques for the determination of uranium, preconcentration procedures are opportune, and several methods have been performed using several separation techniques. $^{9-12}$ Of these, cloud point extraction (CPE) is an impressive alternative to conventional solvent extraction. CPE has frequently been applied in methods for pre-concentration and determination of various ionic and molecular species in several samples. ${ }^{13-19}$ The advantages and limitations of this technique have been summarized in recent reviews. ${ }^{20,21}$ The mixed micellemediated extraction (mixed-MME) system is becoming an important and practical application of the use of surfactants in analytical chemistry. ${ }^{22,23}$ Mixed-MME was used to the preconcentration of organic compounds ${ }^{24-26}$ and metal cations. ${ }^{27-29}$

\footnotetext{
* Author to whom correspondence should be addressed. (E-mail: mbgholivand@yahoo.com)
} 
<smiles>[R]c1c(S(=O)(=O)O)cc2cc(S(=O)(=O)O)cc(O)c2c1O</smiles>

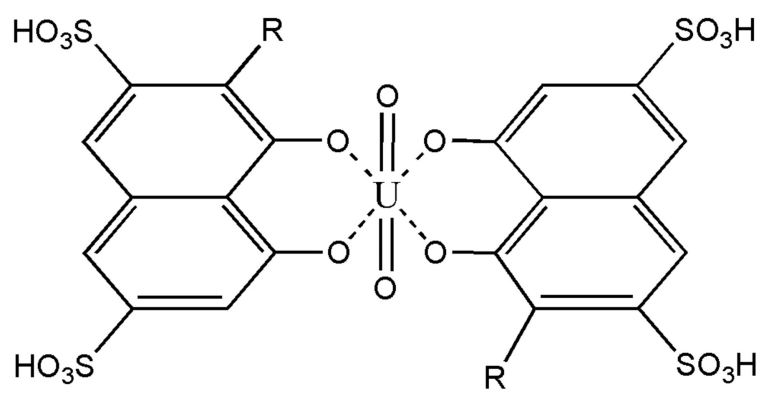<smiles>[R]=NC=Nc1ccccc1</smiles>

Scheme 1. Chemical structures of CTR and CTR-U(VI) complex.

The chromotrope 2R (CTR) (Scheme 1) is a dye derived from the chromotropeic acid and has been used as complexing agent for uranium ${ }^{30} \mathrm{U}(\mathrm{IV})$ reacts with CTR and form a negative charge complex $\left(\mathrm{ML}_{2}\right)$ which in the presence of CTAB can subsequently be trapped in the surfactant micelles (e.g. Triton X-114) and separated from the aqueous phase.

\section{EXPERIMENTAL}

\section{Apparatus}

An Agilent-Packard 8453 diode array spectrometer controlled by a Hewllet-Packard computer and equipped with $1 \mathrm{~cm}$ path length quartz cell was used for absorption measurements. A Metrohm pH meter (model 632) with a combined glass electrode was utilized for $\mathrm{pH}$ measurements. A thermostat (Schvtzart DIN 40050IP20, Germany) was used to maintain the desired temperature within $\pm 1.0^{\circ} \mathrm{C}$. A centrifuge (Hittach D-78532, Germany) was used to accelerate the phase separation process.

\section{Reagents}

All reagents were of analytical reagent grade. The water utilized in all studies was double-distilled and deionized. The surfactants, polyethylene glycol tert- octylphenyl ether (Triton X-114) and cetyltrimethylammonium bromide (CTAB) (Fluka, Buches, Switzerland) were used without further purification. Stock solution of uranium at a concentration of $1000 \mu \mathrm{g} \mathrm{mL}^{-1}$ was prepared by dissolving appropriate amount of uranium acetate salt in double distilled water. Working standard solutions were obtained by dilution of the stock solution. A solution of $1.0 \times 10^{-2} \mathrm{~mol} \mathrm{~L}^{-1}$ of chromotrope $2 \mathrm{R}$ (Fluka, Buches, Switzerland) was prepared by dissolving appropriate amounts of this reagent in double distilled water. The solution $\mathrm{pH} 8 \pm 0.2$ was adjusted with 20 mM HEPES (4-(2-hydroxyethyl)-1-piperazineethanesulfonic acid) buffer. N,N-dimethylformamide (DMF) and potassium iodide were purchased from Merck (Darmstadt, Germany). These solutions were prepared daily and were stable during the day. The materials and vessels used for trace analysis were kept in $10 \%$ nitric acid for at least $48 \mathrm{~h}$ and subsequently washed four times with deionized water before use.

\section{Procedure}

For the CPE, a proper amount of a uranium (VI) standard solution was transferred to a $10 \mathrm{~mL}$ centrifuge tube, $1.5 \mathrm{~mL}$ of the $1.0 \times 10^{-4} \mathrm{~mol} \mathrm{~L}^{-1}$ chromotrope $2 \mathrm{R}$ solution and $1 \mathrm{~mL}$ HEPES buffer solution were added. This was followed by the addition of $1.5 \mathrm{~mL}$ of $2.0 \times 10^{-4} \mathrm{~mol}$ $\mathrm{L}^{-1}$ surfactant CTAB solution, $1.0 \mathrm{~mL}$ of $0.2 \%(v / v)$ of Triton X-114 solution and $0.5 \mathrm{~mL}$ of $0.015 \mathrm{~mol} \mathrm{~L}^{-1}$ of KI solution. The solution was taken up to the mark with double distilled water. The tubes were kept for $20 \mathrm{~min}$ in the thermostatic bath at $70{ }^{\circ} \mathrm{C}$. Subsequently, separation of the phases was accelerated by centrifugation for $15 \mathrm{~min}$ at $4000 \mathrm{rpm}$. The surfactant-rich phase became viscous. The phases were cooled down in an ice bath in order to increase the viscosity of the surfactant-rich phase. The bulk aqueous phase was easily decanted by simply inverting the tube. Later, in order to decrease the viscosity and facilitate sample handling, $0.3 \mathrm{~mL}$ of DMF was added to the surfactant-rich phase and a 100 $\mu \mathrm{l}$ of the solution was transferred into a quartz cell containing the blank DMF to measure the absorbance of the solution at $580 \mathrm{~nm}$.

\section{RESULTS AND DISCUSSION}

\section{Method Development}

The chromotrope $2 \mathrm{R}$ (CTR) is a dye derived from the chromotropeic acid. It presents a chelating power for $\mathrm{U}(\mathrm{VI})$ and forms a $\mathrm{ML}_{2}$ (metal to ligand) complex with uranium (VI). ${ }^{29}$ In addition, in the primary experiment, it was found that the addition of some equivalent of $\mathrm{U}(\mathrm{VI})$ to aqueous solution of CTR resulted in a fast change in the color of the solution. CTR as an anionic dye shows maximum absorbance at $520 \mathrm{~nm}$ at $\mathrm{pH} 8$. 


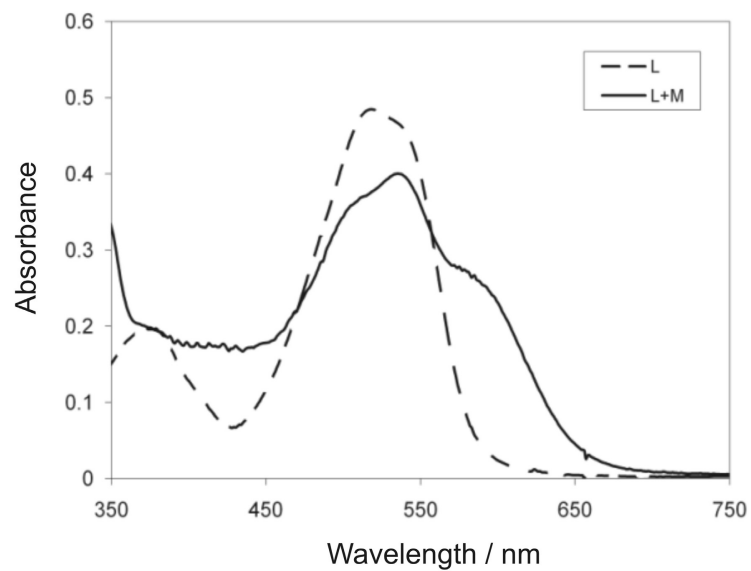

Figure 1. Absorption spectra for chromotrope 2R (discrete line) and its complex with uranium (VI) (solid line) in surfactant-rich phase. Conditions: chromotrope $2 \mathrm{R}, 1.5 \times 10^{-4} \mathrm{~mol}$ $\mathrm{L}^{-1}$; uranium (VI) , $5.00 \mathrm{ng} \mathrm{mL} \mathrm{L}^{-1}$; KI, $0.015 \mathrm{~mol} \mathrm{~L}^{-1}$; CTAB, $2 \times 10^{-4} \mathrm{~mol} \mathrm{~L}^{-1}$; Triton X-114, $0.2 \%(v / v) ; \mathrm{pH}=8.0$.

$\mathrm{U}(\mathrm{VI})$ in this medium reacts with CTR in the presence of CTAB and Triton X-114, the absorbance of solution decreases at $520 \mathrm{~nm}$ and produces a new band with maximum absorbance at about $580 \mathrm{~nm}$ (Figure 1). The solution became turbid after addition of the iodide ion. Therefore the ternary complex of U(IV)-CTR-CTAB can be extracted by CPE method. Thus, for finding the optimum conditions, the influence of various parameters on extraction efficiency was investigated.

\section{Effect of pH}

The separation of uranium (VI) by CPE method involves prior formation of a complex with sufficient hydrophobicity to be extracted into the small volume of surfactantrich phase. The $\mathrm{pH}$ plays an important role on metalchelates formation and subsequent extraction. The effect of $\mathrm{pH}$ on the signal intensity of uranium (VI) with CTR was studied in $\mathrm{pH}$ range $2.0-12.0$, and the experimental results are shown in Figure 2. As can be seen, when the medium $\mathrm{pH}$ was lower than 8.0, only part of the uranium (VI) were extracted into the surfactant-rich phase due to the incomplete formation of U(VI)-CTR complexes in this $\mathrm{pH}$ range. Maximum absorbance was obtained at $\mathrm{pH}$ 8.0. When the medium $\mathrm{pH}$ was higher than 8.0, the hydrolysis reaction plays a dominant role, the hydrolysis of uranium (VI) would occur prior to their chelation with CTR which lead to the low extraction efficiency. Hence, $\mathrm{pH} 8.0$ was chosen as the working $\mathrm{pH}$.

\section{Effect of CTR Concentration}

In general, the concentration of the chelating reagent has a remarkable influence on the extraction efficiency. In order to select the optimal concentration of CTR, with the

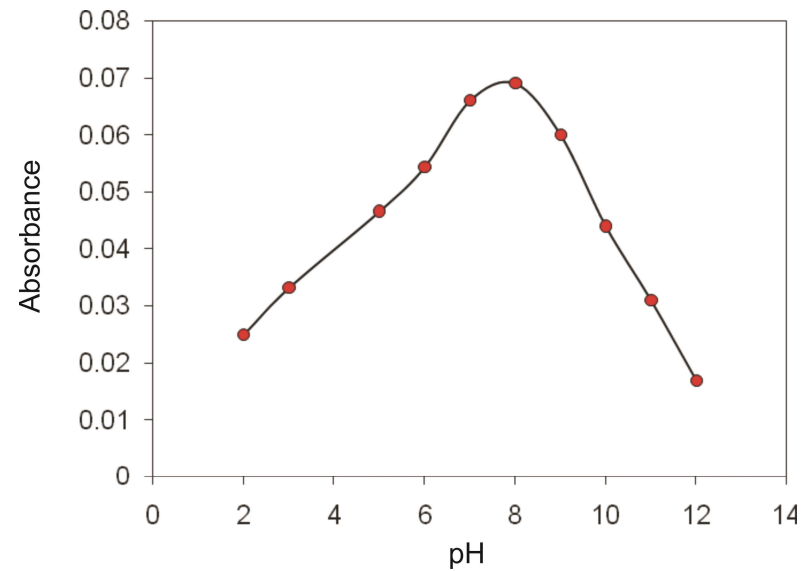

Figure 2. Effect of $\mathrm{pH}$ on the $\mathrm{CPE}$ of $5.00 \mathrm{ng} \mathrm{mL} \mathrm{L}^{-1}$ uranium (VI). Other conditions are as in Figure 1.

other experimental parameters remaining constant, the effect of CTR concentration in the range of (0.33-2.5) $\times 10^{-4} \mathrm{~mol} \mathrm{~L}^{-1}$ was investigated. By increasing the ligand concentration (Figure 3 ), the conditions of complex formation will be better and the concentration of the formed complex will be increased, therefore, the absorbance will be increased too (to $1.5 \times 10^{-4}$ ). But from the optimum concentration on, the whole amount of metal ions will be consumed for the formation of the complex and no signal is detected for uranium in aqueous phase and the conditions for complex formation are not suitable anymore, therefore, the amount of ligand doesn't have any role on forming the complex and the absorbance will be fixed.

\section{Effect of Surfactants Concentration}

In the preliminary experiments it is observed that the addition of the neutral surfactant such as Triton X-114

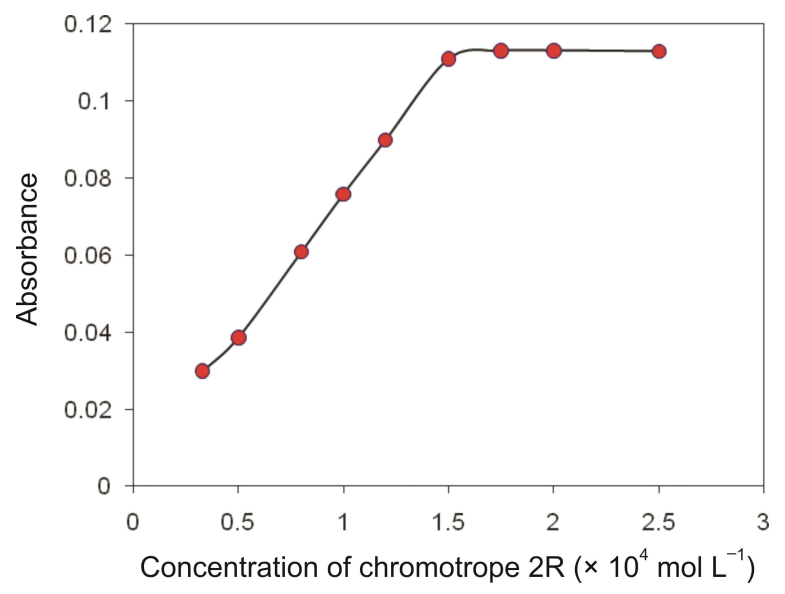

Figure 3. Effect of concentration of complexing agent on $\mathrm{CPE}$ of $5.00 \mathrm{ng} \mathrm{mL} \mathrm{m}^{-1}$ uranium (VI). Experimental conditions: Triton X-114, $0.2 \%(v / v)$; CTAB, $2 \times 10^{-4} \mathrm{~mol} \mathrm{~L}^{-1}$; KI, 0.015 $\mathrm{mol} \mathrm{L}-1$ and $\mathrm{pH}=8.0$. 


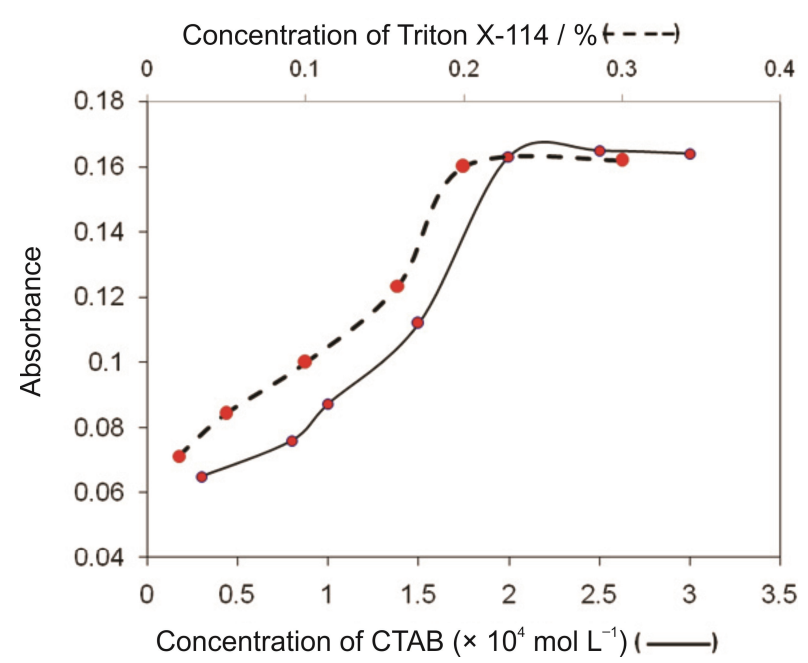

Figure 4. Absorbance of the complex as a function of CTAB (solid line) and Triton X-114 (dashed line) concentrations. Conditions: $5.00 \mathrm{ng} \mathrm{mL}{ }^{-1} \mathrm{U}$ (VI); $1.5 \times 10^{-4} \mathrm{~mol} \mathrm{~L}^{-1} \mathrm{CTR}$; $0.015 \mathrm{~mol} \mathrm{~L}^{-1} \mathrm{KI} ; \mathrm{pH}=8.0$.

to ternary complex of U(VI) ion-CTR-CTAB and heating, makes the solution turbid. This shows that the ternary complex can be extracted by CPE method. Therefore, the effect of ionic (CTAB) and nonionic surfactant (Triton X-114) concentrations on the analytical response of $5 \mathrm{ng} \mathrm{mL} \mathrm{mL}^{-1}$ of uranium (VI) were investigated. The results are shown in Figure 4. As can be seen the measured absorbance reached its maximum at more than 0.2 $\%(v / v)$ of Triton X-114 and $2.0 \times 10^{-4} \mathrm{molL}^{-1}$ of CTAB, indicating that quantitative extraction by cloud point method was obtained. By increasing the concentrations of the surfactants due to increase the amount of formed micelles, the extraction percentage will be increased. Therefore, $2.0 \times 10^{-4} \mathrm{~mol} \mathrm{~L}^{-1}$ and $0.2 \%(v / v)$ were selected as the optimum amounts of ionic and nonionic surfactants for subsequent uses. Thus, by using Triton $\mathrm{X}-114$ and CTAB as a mixed surfactant agent, the test solution could be separated easily into two phases and the bulk aqueous phase could be decanted after centrifugation.

\section{Effects of Equilibration Temperature and Time}

Equilibration time and temperature are among the most important parameters to be optimized in order to achieve easy phase separation and efficient preconcentration in cloud point extraction processes. It is reported that the greatest analyte preconcentration factor is achieved when the CPE process is conducted with equilibration temperatures that are well above the cloud point temperature of the surfactant. ${ }^{31}$ Increasing time and temperature is necessary for having complete reaction, facile separation and complete pre-concentration, therefore, by increasing them the absorbance will be

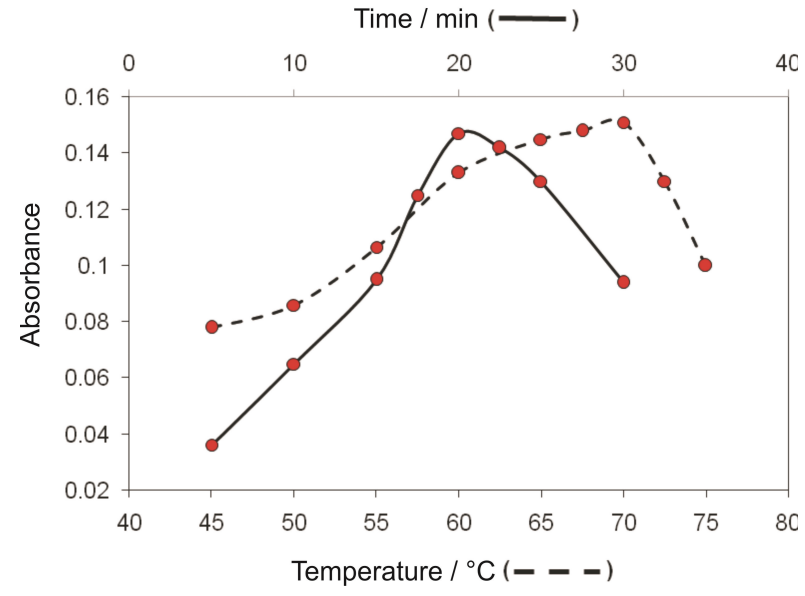

Figure 5. Effect of equilibration time (solid line) and temperature (dashed line) on the CPE of $5.00 \mathrm{ng} \mathrm{mL}^{-1} \mathrm{U}(\mathrm{VI})$. Experimental conditions: $1.5 \times 10^{-4} \mathrm{~mol} \mathrm{~L}^{-1}$ CTR; Triton X-114, $0.2 \%(v / v)$; CTAB, $2 \times 10^{-4} \mathrm{~mol} \mathrm{~L}^{-1}$; KI, $0.015 \mathrm{~mol} \mathrm{~L}^{-1}$; $\mathrm{pH}=8.0$.

increased. From the optimum points on, there is a probability for collapsing the formed complex and weak clouding of the surfactants, therefore, absorbance will be decreased. The dependency of extraction recovery to the incubation time and temperature was studied in the range 5-30 min and $45-75^{\circ} \mathrm{C}$, respectively. The results showed that an equilibration time of $20 \mathrm{~min}$ and equilibration temperature of $70{ }^{\circ} \mathrm{C}$ are adequate to obtain quantitative extraction (Figure 5).

\section{Optimization of other Cloud Point Extraction Parameters}

Addition of salts can cause cationic surfactant solutions to separate into immiscible surfactant rich and surfactant-poor phases. Therefore, the effects of a few salts, such as $\mathrm{NaCl}, \mathrm{NaF}, \mathrm{KNO}_{3}, \mathrm{KBr}$ and $\mathrm{KI}$, on the $\mathrm{CPE}$ behavior were investigated. It was found that the presence of KI induced the phase separation and resulted in extraction of maximal efficiency. As mentioned before the resulted complex of uranium and CTR is an anionic complex and it must be converted to an uncharged form in order to be trapped in the surfactant micelles. CTAB can interact with the complex as an individual molecule or aggregates. On the other hand, cationic surfactants react by ion pair formation with the anionic uranium complex to form a ternary complex involving surfactant monomers. This uncharged complex can be trapped in the triton X-114 as surfactant micelles. Furthermore, the excess of CTAB monomers may be used as co surfactant and thus, potassium iodide was used to reduce the repulsion between the monomers. On the other hand, potassium and iodide ions with large ionic size and less charge density reduces the repulsion of cationic surfac- 


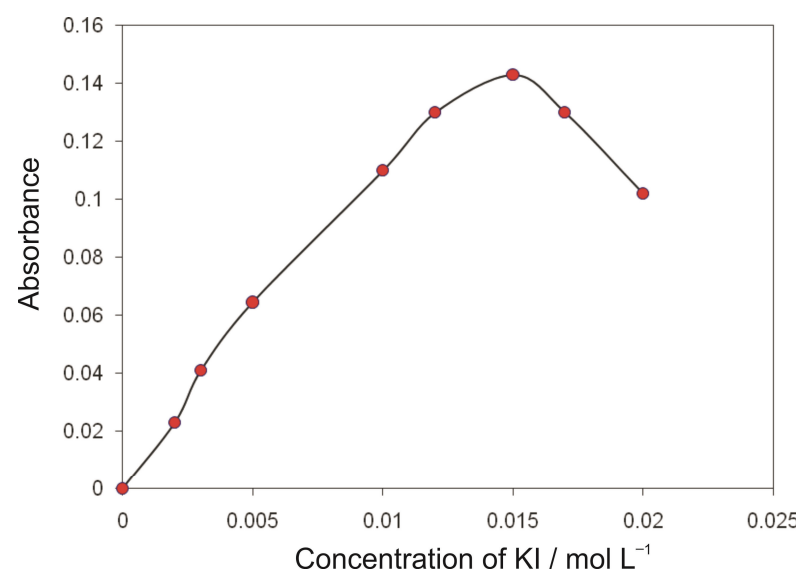

Figure 6. Effect of iodide concentration on the CPE of 5.00 ng $\mathrm{mL}^{-1} \mathrm{U}(\mathrm{VI})$. Conditions: CTAB, $2 \times 10^{-4} \mathrm{~mol} \mathrm{~L}^{-1}$; Triton $\mathrm{X}-114,0.2 \%(v / v)$; CTR $1.5 \times 10^{-4} \mathrm{~mol} \mathrm{~L}^{-1}$ and $\mathrm{pH}=8.0$.

tant by better ion pair formation induces the phase separation and increases the extraction efficiency. These results are consistence with the previous report. ${ }^{32}$ The effect of iodide concentration was studied in the range $0.00-0.02 \mathrm{~mol} \mathrm{~L}^{-1}$. The results demonstrated that the maximum analytical signals of uranium (VI) was achieved at concentration $0.015 \mathrm{~mol} \mathrm{~L}^{-1}$ and decreased at higher concentrations (Figure 6). Therefore, 0.015 mol L $\mathrm{L}^{-1}$ of KI was used in further uses.

The surfactant-rich phase obtained after CPE is very viscous. In order to decrease the viscosity of surfactant-rich phase and facilitate its transfer into a spectrophotometric cell ,handling and absorbance measurements various solvents such as carbon tetrachloride $\left(\mathrm{CCl}_{4}\right)$, ethanol $\left(\mathrm{C}_{2} \mathrm{H}_{5} \mathrm{OH}\right)$, methanol $\left(\mathrm{CH}_{3} \mathrm{OH}\right)$, dimethyl sulfoxide (DMSO), tetrahydrofuran (THF), methyl isobutyl ketone (MIBK), and N,N-dimethylformamide (DMF) were tested as diluents. The results show that the highest signal was found when DMF was used as diluent. By the use of the other solvents for dissolving the rich surfactant phase, much amount of the solvent is required that not only brings more cost but also causes both environmental pollution and decreasing the preconcentration factor. Therefore, $0.3 \mathrm{~mL}$ of DMF was added to the extracted phase and its absorbance was measured.

The high levels of rate and time are required for centrifuge to have a more suitable separation of two phases, but temperature will be decreased during a long time for this process which causes more mix two phases together and subsequently decreases the extraction yield. It should be noted that high temperature can collapse the formed complex. The effect of the centrifugation time on extraction efficiency was the other parameter that was studied within a range 5-30 min. A Centrifuge time of $15 \mathrm{~min}$ at $4000 \mathrm{rpm}$ was selected for the entire procedure, since analyte extraction in this time is
Table 1. Tolerance limit of diverse ions on the determination of $5.00 \mathrm{ngmL}^{-1} \mathrm{U}(\mathrm{VI})$

\begin{tabular}{lc}
\hline \multicolumn{1}{c}{ Interfering ion } & $\begin{array}{c}\text { Interfering ion/U(VI) } \\
\left(\mathrm{ng} \mathrm{mL} \mathrm{m}^{-1}\right)\end{array}$ \\
\hline $\mathrm{Bi}^{3+}, \mathrm{Zr}^{4+}, \mathrm{Al}^{3+}, \mathrm{Fe}^{3+}$ & $40(500)^{(\mathrm{a})}$ \\
$\mathrm{Ni}^{2+}, \mathrm{Pb}^{2+}, \mathrm{Cd}^{2+}, \mathrm{Co}^{2+}, \mathrm{Ca}^{2+}, \mathrm{Cu}^{2+}$ & 2000 \\
$\mathrm{Cr}^{3+}, \mathrm{Ce}^{3+}, \mathrm{Ag}^{+}$ & 2500 \\
$\mathrm{Na}^{+}, \mathrm{Li}^{+}, \mathrm{K}^{+}$ & 4000 \\
$\mathrm{SO}_{4}{ }^{2-}, \mathrm{NO}_{3}{ }^{-}, \mathrm{Cl}^{-}$ & 60000 \\
\hline (a) $\mathrm{After}$ addition of $0.5 \mathrm{~mL}$ EDTA $0.1 \%$ &
\end{tabular}

(a) After addition of $0.5 \mathrm{~mL}$ EDTA $0.1 \%$.

almost quantitative, since complete separation occurred at this time, and no considerable improvement was observed for longer periods of time.

\section{Effect of Foreign ions}

In order to evaluate the performance of this procedure, the highest tolerability of various common interfering ions were studied. Interferences may occur mainly due to competition of other existing ionic species in the test solution that may form complexes with the CTR. Therefore, the tolerable limits of various foreign ions were studied in solution containing $5.00 \mathrm{ng} \mathrm{mL}^{-1}$ of uranium (VI), by keeping the relative error between $\pm 5 \%$. It was found that most of the investigated species did not interfere even when present in 2000-fold excess over uranium (VI) (Table 1). The ions $\mathrm{Al}^{3+}, \mathrm{Bi}^{3+}, \mathrm{Fe}^{3+}$ and $\mathrm{Zr}^{4+}$ in concentrations higher than the tolerance ratios reported in Table 1 have influence on the proposed CPE of uranium (VI) under the selected conditions. The interfering effect of mentioned ions was completely removed in the presence of $0.1 \%$ of EDTA.

\section{Analytical Characteristics}

Table 2, summarizes the analytical characteristics of the optimized method, including regression equation, linear range, limit of detection, pre-concentration and improvement factors. The limit of detection and limit of quantification are defined as $\mathrm{C}_{\mathrm{LOD}}=3 \mathrm{~S}_{\mathrm{B}} / m$ and $\mathrm{C}_{\mathrm{LOQ}}$ $=10 \mathrm{~S}_{\mathrm{B}} / m$ where $\mathrm{S}_{\mathrm{B}}$ and $m$ are standard deviation of the blank and slope of the calibration curve, respectively. By the use of the foregoing formula 0.035 and 0.116 $\mathrm{ng} \mathrm{mL} \mathrm{m}^{-1}$ are obtained for LOD and LOQ, respectively. Because the amount of uranium (VI) in $10 \mathrm{~mL}$ of sample solution is measured after preconcentration by cloud point extraction in a final volume of $0.5 \mathrm{~mL}(0.2$ $\mathrm{mL}$ surfactant-rich phase and $0.3 \mathrm{~mL} \mathrm{DMF})$, the maximum preconcentration factor of the solution is 20 . The improvement factor defined as the ratio of the slope of the calibration graph for CPE method to that of the calibration graph in micellar media without preconcentration, was 100 . The relative standard deviation (RSD) was $3.3 \%$ and $2.9 \%$ for concentrations of

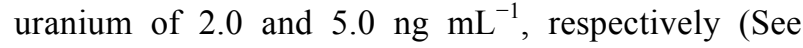
Table 2). 
Table 2. Analytical features of the proposed method

\begin{tabular}{|c|c|}
\hline Analytical parametar & Uranium(VI) \\
\hline Linear range $^{(\mathrm{a})}$ & $0.2-10.0\left(\mathrm{ng} \mathrm{mL}^{-1}\right)$ \\
\hline Regression equation $^{(a)}$ & $0.011 \mathrm{C} \mathrm{ng} \mathrm{mL}^{-1}+0.090(n=8)$ \\
\hline Correlation coefficient $\left(r^{2}\right)^{(\mathrm{a})}$ & 0.997 \\
\hline Linear range $^{(b)}$ & $20-1000\left(\mathrm{ng} \mathrm{mL}^{-1}\right)$ \\
\hline Regression equation $^{(b)}$ & $0.00011 \mathrm{C} \mathrm{ng} \mathrm{mL}^{-1}+0.080(n=15)$ \\
\hline Correlation coefficient $\left(r^{2}\right)^{(\mathrm{b})}$ & 0.998 \\
\hline Improvement factor & 100 \\
\hline Maximum Preconcentration factor & 20 \\
\hline Repeatability (RSD, \%) & $3.3\left(\right.$ for $\left.2.0 \mathrm{ng} \mathrm{mL}^{-1}, n=6\right)$ \\
\hline Repeatability (RSD, \%) & 2.9 (for $5.0 \mathrm{ng} \mathrm{mL}^{-1}, n=6$ ) \\
\hline Limit of detection & $0.0350\left(3 S_{\mathrm{b}} / \mathrm{ng} \mathrm{mL}^{-1}\right)(n=7)$ \\
\hline Limit of qualification & $0.116\left(10 S_{\mathrm{b}} / \mathrm{ng} \mathrm{mL}^{-1}\right)(n=7)$ \\
\hline
\end{tabular}

(a) After preconcentration.

(b) Before preconcentration.

Table 3. Determination of U(VI) in the water samples

\begin{tabular}{|c|c|c|c|}
\hline Sample & $\mathrm{U}(\mathrm{VI})$ added $/ \mathrm{ng} \mathrm{mL} L^{-1}$ & $\mathrm{U}(\mathrm{VI})$ found $/ \mathrm{ng} \mathrm{mL} L^{-1}$ & Recovery U(VI) / \% \\
\hline \multirow{2}{*}{ Tap Water } & 2.00 & $2.03 \pm 0.04$ & 101.5 \\
\hline & 5.00 & $4.82 \pm 0.01$ & 96.4 \\
\hline \multirow{2}{*}{ Well Water } & 2.00 & $2.03 \pm 0.02$ & 101.5 \\
\hline & 5.00 & $4.80 \pm 0.04$ & 96.0 \\
\hline
\end{tabular}

\section{Application}

In order to evaluate the analytical applicability of the proposed method, it was applied to the determination of uranium in water samples. Reliability was checked by spiking the sample and the accuracy of the method was examined by recovery experiment. The results of the CPE experimental are shown in Table 3. The obtained recoveries varying between 96 and $102.5 \%$ proved that this procedure is not affected by the matrix and can be applied satisfactorily to the determination of uranium in water samples.

\section{CONCLUSION}

We have presented a new concept of increasing the hydrophobic nature of cationic micelles with nonionic surfactant for inducing the cloud point phase separation. The use of micellar systems as an alternative to other methods of separation and preconcentration offers several advantages including experimental convenience, safety and being an inexpensive method with low toxicity. Its analytical applicability has been demonstrated by extraction of hydrophilic anionic species of uranium.

Table 4. Comparison of the performance of the proposed method with that of other reported methods for the preconcentration Spectrophotometric determination of uranium (VI)

\begin{tabular}{|c|c|c|c|c|}
\hline Analytical method & Detection limit & Linear range & $\begin{array}{l}\text { Preconcentra- } \\
\text { tion factor }\end{array}$ & References \\
\hline $\begin{array}{l}\text { micelle-mediated extraction / spectrophotometric } \\
\text { determination }\end{array}$ & $0.06 \mathrm{ng} \mathrm{mL}^{-1}$ & $0.20-10.00\left(\mathrm{ng} \mathrm{mL}^{-1}\right)$ & 14.3 & 32 \\
\hline Spectrophotometry & $2.0 \mathrm{ng} \mathrm{mL}^{-1}$ & $5-200\left(\mu g 1^{-1}\right)$ & - & 10 \\
\hline Spectrophotometry & $11 \mathrm{ng} \mathrm{mL}^{-1}$ & $15-300\left(\mathrm{ng} \mathrm{mL}^{-1}\right)$ & 62 & 33 \\
\hline $\begin{array}{l}\text { inductively coupled plasma optical emission spectrometry } \\
\text { (ICP OES). }\end{array}$ & $0.3 \mu \mathrm{g} \mathrm{L}^{-1}$ & $1-1500\left(\mu \mathrm{g} \mathrm{L}^{-1}\right)$ & 100 & 34 \\
\hline $\begin{array}{l}\text { micelle-mediated extraction / inductively coupled plasma- } \\
\text { optical emission spectrometry }\end{array}$ & $1.0 \mu \mathrm{g} \mathrm{L}^{-1}$ & $2.5-1240\left(\mu \mathrm{g} \mathrm{L}^{-1}\right)$ & - & 35 \\
\hline Solid phase extraction/ spectrophotometric determination & $1 \mu \mathrm{g} \mathrm{L}^{-1}$ & $1.35-217\left(\mu \mathrm{g} \mathrm{mL}^{-1}\right)$ & 400 & 36 \\
\hline Colorimetry & $0.3 \mu \mathrm{g} \mathrm{mL}^{-1}$ & - & - & 37 \\
\hline Membrane optode & $50 \mathrm{ng} \mathrm{mL}^{-1}$ & $0.01-0.11\left(\mu \mathrm{mol} \mathrm{L}^{-1}\right)$ & - & 38 \\
\hline Preconcentration/spectrophotometric determination & $0.50 \mu \mathrm{gL}^{-1}$ & - & 100 & 39 \\
\hline CPE & $0.035 \mathrm{ng} \mathrm{mL}^{-1}$ & $0.20-10.00\left(\mathrm{ng} \mathrm{mL}^{-1}\right)$ & 20 & $\begin{array}{l}\text { Proposed } \\
\text { method }\end{array}$ \\
\hline
\end{tabular}


The limits of detection of uranium achieved (Table 4) are superior to reported procedures. ${ }^{10,32-39}$ This method allows the determination of low levels of uranium (VI) using molecular absorption spectrometry. It was successfully applied for the determination of uranium in various water samples.

Acknowledgements. We would like to thank the research council at the Razi University for their cooperation and support of this work.

\section{REFERENCES}

1. M. L. Zamora, B. L. Tracy, J. M. Zielinski, D. P. Meyerhof, and M. A. Moss, Toxicol. Sci. 43 (1998) 68-77.

2. D. E. McClain, K. A. Benson, T. K. Dalton, J. Ejnik, C. A. Emond, S. J. Hodge, J. F. Kalinich, M. A. Landauer, A. C. Miller, T. C. Pellmar, M. D. Stewart, and V. Villa, J. Xu, Sci. Total Environ. 274 (2001) 115-118.

3. A. Kimaro, L. A. Kelly, and G. M. Murray, Separ. Sci. Technol. 40 (2005) 2035-2052.

4. K. Oguma, T. Suzuki, and K. Saito, Talanta 84 (2011) 1209-1214.

5. A. Milliard, M. D. Jézéquel, and D. Larivière, Anal. Chim. Acta 684 (2011) 40-46.

6. B.Welz and M. Sperling, Atomic Absorption Spectrometry, Wiley-VCH, New York, 1999.

7. A. Montaser, D. W. Golightly, Inductively Coupled Plasmas in Analytical Atomic Spectrometry, 2nd edn. VCH, New York, 1992.

8. D. M. Goltz, D. C. Gregoire, J. P. Byme, and C. L. Chakrabarti, Spectrochim. Acta Part B 50 (1995) 803-814.

9. Z. F. Liu and S. P. Liu, Analyst 116 (1991) 95-98.

10. P. Metilda, K. Sanghamitra, J. M. Gladis, G. R. K. Naidu, and T. P. Rao, Talanta 65 (2005) 192-200.

11. J. M. Gladis and T. P. Rao, Anal. Bioanal. Chem. 373 (2002) $867-872$.

12. P. Taechangam, J. F. Scamehorn, S. Osuwan, and T. Rirksomboon, Colloids Surf. A 347 (2009) 200-209.

13. J. Chen, J. Mao, X. Mo, J. Hang, and M. Yang, Colloids Surf. A 345 (2009) 231-236.

14. D. Citak and M. Tuzen, Food Chem. Toxicol. 48 (2010) 1399-1404.
15. P.Liang and J. Yang, J. Food. Compos. Anal. 23 (2010) 95-99.

16. P. Liang, J. Li, and X. Yang, Microchim. Acta 152 (2005) 47-51.

17. D. L. G. Borges, M. A. M. S. Veiga, V. L. A. Frescura, B. Welz, and A. J. Curtius, J. Anal. At. Spectrom. 18 (2003) 501-507.

18. T. D. Maranhao, D. L. G. M. Borges, A. M. S. Veiga, and A. J. Curtius, Spectrochim. Acta Part B 60 (2005) 667-672.

19. M. A. M. Silva, V. L. A. Frescura, and A. J. Curtius, Spectrochim. Acta Part B 56 (2001) 1941-1949.

20. M. D. Pereira and M. A. Z. Arruda, Microchim. Acta 141 (2003) 115-131.

21. M. A. Bezerra, M. A. Z. Arruda, and S. L. C. Ferreira, Appl. Spectroscopy Rev. 40 (2005) 269-299.

22. J. Chen and T. K. Chuan, Anal. Chim. Acta 434 (2000) 325-330.

23. A. Afkhami, T. Madrakian, and A. Maleki, Anal. Biochem. 347 (2005) 162-164.

24. E. J. Kim and D. O. Shah, Langmuir 18 (2002) 10105-10108.

25. B. S. Valaulikar and C. J. Manohar, J. Colloids Interf. Sci. 108 (1985) 403-406.

26. J. W. Kang, G. De Reymaeker, A. Van Schepdael, E. Roets, and J. Hoogmartens, Electrophoresis 22 (2001) 1356-1362.

27. E. K. Paleologos, A. G. Vlessidis, M. I. Karayannis, and N. P. Evmiridis, Anal. Chim. Acta 477 (2003) 223-231.

28. D. L. Giokas, J. Antelo, E. K. Paleologos, F. Arce, and M. I. Karayannis, J. Environ. Monitor. 4 (2002) 505-504.

29. M. B. Gholivand, A. Babakhanian, and E. Rafiee, Talanta 76 (2008) 503-508.

30. O. Braun, C. Contino, M. H. Henge-Napoli, E. Ansoborlo, and B. Pucci, Analusis 27 (1999) 65-68.

31. R. P. Frankewich and W. L. Hinze, Anal. Chem. 66 (1994) 944-954.

32. T. Madrakian, A. Afkhami, and A. Mousavi, Talanta 71 (2007) 610-614.

33. F. Shemirani, R. R. Kozani, and M. R. Jamali, Sep. Sci. Technol. 40 (2005) 2527-2537.

34. S. R. Yousefi, S. J. Ahmadi, F. Shemirani, M. R. Jamali, and M. S. Niasari, Talanta 80 (2009) 212-217.

35. S. Shariati, Y. Yamini, and M. K. Zanjani, J. Hazard. Mater. 156 (2008) 583-590.

36. S. Sadeghi and E. Sheikhzadeh, J. Hazard. Mater. 163 (2009) 861-868.

37. J. M. Joshi, P. N. Pathak, A. K. Pandey, and V. K. Manchand, Talanta 76 (2008) 60-65.

38. Y. Kalyan, A. K. Pandey, G. R. K. Naidu, and A. V. R. Reddy, Spectrochim. Acta Part A 74 (2009) 1235-1241.

39. J. B. Ghasemi and E. Zolfonoun, Talanta 80 (2010) 1191-1197. 